\title{
SOROTAN KAJIAN LEPAS: TEORI DAN AMALAN DALAM PENYELIDIKAN ISLAM
}

\author{
Oleh: \\ Idris Awang \\ Rahimin Affandi Abdul Rahim
}

\begin{abstract}
The article attempts to discuss the significance and functions of review literature in research especially as guide to young researchers. Basically, the review enables a researcher to have an up-to-date understanding of the research problem and to avoid him from attempting unnecessarily to understand what has been fully understood. The review will help the researcher to have relevant information of the context of the problem because a problem does not exist by itself, there must be certain relationship with other problems. This is essential when trying to find solution to the problem. The review also exposes the researcher to the related theories that will enable him to plan the research appropriately.
\end{abstract}

Meneliti disertasi dan tesis aliran pengajian kemanusiaan secara umum dan Pengajian Islam secara khususnya didapati bahawa sorotan kajian lepas atau literature review kurang diberi perhatian yang serius. Malah ada setengahnya hanya sekadar untuk memenuhi syarat yang diperlukan pada sesebuah disertasi atau tesis. Perbincangannya mendatar dan tidak menampakkan dengan jelas kaitan dengan masalah yang akan dikaji. Ulasan kajian lepas seperti itu menampakkan bahawa pengkaji tidak berupaya untuk melihat kajiannya dalam konteks kajian-kajian sebelum itu. Beliau mungkin juga beranggapan bahawa kajiannya adalah dalam ruang atau 
Jurnal Fiqh: No. 3 (2006)

bidang yang tersendiri - tidak ada kena mengena dengan kajian-kajian yang pernah dilakukan. Mungkin ada juga yang beranggapan bahawa masalah kajiannya belum dikaji sebelum ini. Hal ini adalah suatu keterlaluan kerana sudah pasti ada di mana-mana kajian-kajian yang pernah dibuat tentang masalah yang boleh dikaitkan dengan masalah yang akan dikaji sama ada secara langsung atau tidak langsung. Setidaknya ada kajian yang boleh dikaitkan dengan bidang masalah yang akan dikaji yangt membolehkan penyelidik merumuskan pengetahuan walau pun sedikit dan terhad untuk dikembangkan dalam kajian yang akan dilaksanakan.

Sesuatu persoalan yang timbul yang ada kaitan dengan objek, manusia, masyarakat, institusi, idea, kefahaman atau perkembangan tertentu sekali ada asal usul atau puncanya, hubungan atau konteksnya yang tersendiri. ${ }^{1}$ Dalam bidang fiqh, misalannya, para ulama' silam mempunyai pandangan mereka sendiri terhadap sesuatu berasaskan kemampuan intelektual mereka, keadaan dan realiti masyarakat pada zaman mereka. ${ }^{2}$ Seseorang yang mengkaji masalah fiqh tertentu dalam masyarakat yang serba maju sekarang tidak boleh menganggap masalah itu berasingan dari masalah fiqh pada zaman fuqaha' silam itu walau pun jarak masa dan lokalitinya jauh. Penjelasan dari fuqaha' berkenaan pada zaman itu perlu diambil kira untuk membantunya dalam memahami masalah masyarakat sekarang. Menyentuh perkara yang sama, Muhammad Yusof Hashim ketika memulakan perbincangannya tentang pensejarahan Melayu Nusantara mengambil kira perbincangan-perbincangan mengenai pensejarahan Eropah, India dan juga Cina. ${ }^{3}$ Dalam kedua-

1 Martin Terre Blanche and Kevin Durrheim (1999), Research in Practice. Cape Town: University of Cape Town Press, h. 17.

2 Mahmood Zuhdi Hj. Ab. Majid (2001), Dinamisme Pengajian Syariah.

Kuala Lumpur: Akademi Pengajian Islam Universiti Malaya, h. 7-8.

3 Muhammad Yusof Hashim (1988), Persejarahan Melayu Nusantara. Kuala Lumpur: Teks Publishing Sdn. Bhd, Bab 1. 
dua keadaan diatas, iaitu hukum dan pensejarahan, walau pun berlakukan dalam bidang yang berbeza tetapi kerangka tindakan mempunyai persamaan. Pemahaman secara mendalam tentang perbincangan yang lepas adalah amat diperlukan. Penulisan yang ringkas ini akan cuba menjelaskan kepentingan sorotan kajian lepas serta panduan tentang cara untuk menghasilkan suatu sorotan yang baik sebagai persiapan untuk melaksanakan penyelidikan. Misalan-misalan dipetik dari kajian-kajian yang telah dilaksanakan oleh sarjana-sarjana berkenaan.

Fink $^{4}$ menyatakan bahawa sorotan kajian lepas adalah suatu penelitian yang sistematik dan jelas untuk mengenali, menilai dan mentafsir hasil-hasil penulisan oleh penyelidik, cerdik pandai dan juga pengamal dalam bidang berkaitan dengan permasalahan yang akan dikaji. Penelitian ini perlu dicatat dengan sistematik dan boleh dirujuk dengan mudah apabila diperlukan kemudian. Berg ${ }^{5}$ menjelaskan bahawa sorotan kajian lepas ialah penilaian secara terperinci bahan-bahan berkaitan dengan masalah yang akan dikaji. Blanche dan Durrheim ${ }^{6}$ pula berkata menyoroti kajian lepas melibatkan proses identifikasi dan analisis bahanbahan penulisan berkaitan dengan masalah yang akan oleh selidiki. Manakala Blaxter, Hughes dan Tight ${ }^{7}$ mengatakan bahawa sorotan kajian lepas ialah suatu ringkasan dan penilaian yang kritis terhadap bahan-bahan dalam suatu bidang atau masalah berkenaan. Secara ringkasnya dari penjelasan-penjelasan di atas itu dapatlah dikatakan bahawa sorotan kajian lepas ialah proses penelitian, penilaian dan pemahaman secara mendalam hasil kajian dan penulisan yang lepas yang mempunyai kaitan dengan

4 A. Fink (1998), Conducting Research Literature Reviews: From Paper to Internet. Thousand Oak: Sage, h. 3.

5 Bruce L. Berg (1998), Qualitative Research Methods for Social Sciences (3 ${ }^{\text {rd }}$ ed.). Boston: Allyn and Bacon, h. 255.

Martin Terre Blanche and Kevin Durrheim (1999), op.cit.

7 Loriane Blaxter, Christina Hughes \& Malcom Tight (2002), How to Research (ed. 2). Buckingham: Open University Press, h. 122. 
Jurnal Fiqh: No. 3 (2006)

persoalan yang akan dikaji. Hasil dari penelitian ini akan menampakkan ruang atau lompang dalam pengetahuan berkaitan yang harus dilengkapkan. Demikian juga akan memberi input kepada penyelidik dalam memahami persoalan yang akan dikajinya secara lebih mendalam selain dari dapat mengetahui konteks wujudnya masalah itu serta dapat membantunya dalam melaksanakan kajiannya secara berkesan.

Meneliti tesis dan disertasi di perpustakaan kita dapati ada di antaranya hanya sekadar sebuah academic exercise yang mencukupi merit untuk dianugerahkan ijazah pada tahap berkenaan, sama ada sarjana atu doktor falsafah. Kelemahan-kelemahan terdapat di mana-mana, dari penjelasan masalah kajian hinggalah perumusan penemuannya. Membacanya dirasai bahawa penyelidik berkenaan menghadapi masalah dalam memahami pesoalan kajiannya, menentukan jenis data yang diperlukan, memilih rujukan yang sesuai dan autoritatif, memilih kaedah atau kaedah-kaedah yang sesuai untuk mengumpul data yang valid dan mencukupi serta bagaimana untuk membuat analisis yang berkesan terhadap data yang dikumpul itu. Kelemahan-kelemahan yang nyata seperti ini tidak seharusnya berlaku sekiranya penyelidik-penyelidik berkenaan membuat penelitian terhadap kajian-kajian lepas secara betul dan mendalam, meluas serta sistematik sama ada pada kajian yang ada kaitan secara langsung atau tidak langsung.

Faedah asas yang akan diperolehi oleh seseoang penyelidik dari review literature ini ialah pendedahan terhadap rujukan kerana setiap kajian lepas itu sudah pasti akan menyenaraikan rujukan yang telah digunakan sepanjang pengkajian yang telah dilakukan. Selalunya senarai ini memuatkan sumber-sumber yang lebih khusus berkaitan dengan masalah yang dikaji berbanding dengan senarai katalog di perpustakaan yang hanya bersifat umum atau hanya berasas bidang sahaja. Dari senarai seperti itu 
Sorotan Kajian Lepas: Teori dan Amalan Dalam Penyelidikan Islam

dapatlah dipilih rujukan yang sesuai atau paling hampir dengan masalah kajian yang akan diteliti nanti. Selain dari senarai rujukan ada tesis dan disertasi itu melampirkan instrumen kajian yang telah digunakan untuk mengumpul data, dokumen-dokumen yang sukar didapati di tempat lain seperti manuskrip, peta, gambar, perangkaan dan sebagainya. Hampir semua kajian yang menggunakan soalselidik sebagai instrument kajian akan melampirkan borang soalselidik itu. Soalselidik ini sudah tentu telah diuji kesahihan dan kebolehpercayaannya. Kajian yang akan dilaksanakan boleh mengguna borang ini secara sepenuhnya atau boleh diubahsuai sesuai dengan keperluan kajian yang akan dilaksanakan. Adalah tidak salah untuk menggunakan instrument kajian yang telah digunakan oleh penyelidik lain kerana yang digunakan itu bukan datanya. Walau macam mana pun penghargaan perlu dinyatakan terhadap penyelidik itu secara jelas. Suwaid Tapah ${ }^{8}$ dalam disertasinya melampirkan dokumen penting tentang sejarah perundangan di Sabah yang ditemui semasa melaksanakan kajiannya; Nizaita binti Omar' melampirkan 'The Oath of Muslim Physician (FIMA, Kuwait 1981); Suwaid Bin Tapah ${ }^{10}$ melampirkan 164 catitan kes berbagai jenis yang dibawa ke Mahkamah Rayuan Syariah; Farawahida Mohd. Yusof ${ }^{11}$ melampirkan Pengakuan Asaari Mohamad, Imam Asaari al-Tamimi,

8 Suwaid Tapah (1988), "Sejarah Perundangan Islam di Sabah," Disertasi Sarjana, Universiti Malaya.

9 Nizaita Omar (2004), "Pelaksanaan Ibadat Solat Bagi Pesakit: Kajian Hukum Berdasarkan Realiti," tesis Doktor Falsafah, Universiti Malaya.

10 Suwaid Tapah (1996), "Konsep dan Amalan Pembahagian Harta Sepencarian Orang-orang Islam di Malaysia," tesis Doktor Falsafah, Universiti Malaya.

11 Farahwahida Mohd. Yusof (2005), “Keberkesanan Pelaksanaan Fatwa Dalam Menangani Aliran-aliran Kepercayaan di Malaysia: Kajian Kes Terhadap Al-Arqam dan Ahmadiyah Qadiani," tesis Doktor Falsafah, Universiti Malaya. 
Jurnal Fiqh: No. 3 (2006)

Pemuda Bani Tamin Imam al-Mahdi; manakala Raihanah Binti Hj. Azahari ${ }^{12}$ melampirkan Enakmen Kanun Prosedur Mal Syariah Selangor 1991: Kaedah-Kaedah Tatacara Mal (Sulh) Selangor 2001 serta perangkaan kes sulh di Selangor. Dokumen dan manuskrip seperti ini adalah sukar untuk diperolehi dan ianya terhasil dari usaha yang gigih dan memakan masa oleh para penyelidik berkenaan dan seharus dimanfaatkan sepenuhnya oleh para pengkaji akan datang.

Dalam merumuskan hasil kajian lepas berkaitan hubungan etnik di Malaysia, Collin Abraham ${ }^{13}$ mengatakan bahawa ahli sejarah telah memberi penjelasan yang bernilai terhadap persoalan itu pada zaman yang mereka kaji. Mereka juga menjelaskan faktor ekonomi, pendidikan dan politik dalam hubungan kaum itu tetapi, beliau menegaskan, kurang sekali penelitian ditumpukan terhadap punca atau akar umbi dalam permasalahan hubungan kaum itu. Beliau merumuskan:

To this extent their approach to race relations has been oversimplified because the social structure itself had been taken as 'given' and therefore its role in influencing inter-group relationship, particularly those between the different racial groups has been neglected. The originality of this study therefore lies in its attempt to trace relations and its manifestation in racial polarisation to its causal roots in the colonial social structure....

Berasaskan rumusan dari sorotan kajian lepas yang dibuat secara mendalam itu, Collin Abraham meneroka dasar colonial pada zaman berkenaan dengan merujuk kepada dokumen dan manuskrip yang terdapat di Arkib

12 Raihanah Hj. Azahari (2005), "Sulh Dalam Perundangan Islam: Kajian di Jabatan Kehakiman Syariah Selangor Darul Ehsan," tesis Doktor Falsafah, Universiti Malaya.

13 Collin Abraham (2004), The Naked Social Order. Kuala Lumpur: Pelanduk Publication, h. xxiii. 
Negara dan juga di beberapa buah perpustakaan di London untuk mengesan punca dan asal usul polarisasi kaum yang wujud sehingga ke hari ini. Collin Abraham berharap kajiannya akan melengkapkan ruang atau lompang yang tertinggal dalam kajian-kajian lepas.

Blanche dan Durheim ${ }^{14}$ mengatakan bahawa tujuan utama menyoroti kajian lepas ialah untuk memahami masalah yang akan dikaji dan mengenalpasti kelemahan yang ada dalam pefahaman terhadap masalah itu. Hal ini penting kerana ianya akan membolehkan penyelidik mengenalpasti, merumuskan dan menyatakan dengan tepat setiap perkara yang hendak difokuskan dalam kajiannya. Sesuatu masalah yang dikaji biasanya luas dan perlu difokuskan kepada mana-mana aspek yang khusus. Pengetahuan ini memudahkan penyelidik sendiri untuk merancang setiap langkah yang akan diambilnya dalam proses penyelidikannya dan maklumat atau data yang macam mana yang harus dikumpulkannya. Kajian yang mempunyai fokus yang jelas dan khusus lebih mudah ditangani kerana ruang yang akan diliputi adalah jelas berbanding dengan kajian yang sifatnya meluas dan tidak terfokus.

Blaxter, Hughes dan Tight ${ }^{15}$ telah juga mengemukakan beberapa masalah yang dihadapi oleh pelajar-pelajar mereka: tiada penulisan lepas tentang masalah yang hendak dikaji, terlalu banyak bahan yang perlu dibaca, tidak ada lagi perkara yang boleh dikaji kerana semua telah dikaji dan berapa banyakkah bahan yang perlu dibaca. Dalam menghadapi masalah seperti ini penyelidik perlu menggunakan segala kebijaksanaannya untuk memilih bahan atau kajian-kajian yang lepas itu dan mana yang berkaitan dengan masalah yang akan dikajinya.

14 M. T. Blanche \& Durheim (1999), op.cit., h. 18.

15 Loraine Blaxter, Christian Hughes \& Malcom Tight (2002), op.cit., h. $123-127$. 
Jurnal Fiqh: No. 3 (2006)

Kalau masalahnya luas sangat, spesifikkan kepada aspek yang lebih kecil; kalau tiada bahan berkaitan secara langsung, pilih bahan yang paling hampir atau boleh dikaitkan dengan masalah kajiannya; kalau didapati semua aspek telah dikaji, tidak ada salahnya mengulangi kajian ke atas masalah itu sama ada untuk mengesahkan penemuannya, mencabar penemuannya, atau memilih perspektif yang berbeza bagi masalah itu. Pengkaji perlu menggunakan sepenuhnya daya kekritisan dalam melihat dan menilai masalah yang akan dikajinya.

Dalam proses pembacaan peringkat awal ini, penyelidik perlu juga mampu mengawal fokus pembacaannya kepada masalah yang hendak dikajinya kerana pembacaan itu sendiri berkemampuan untuk mengalih fokus pembaca. Seorang calon sarjana meletakkan 'sikap dan kefahaman golongan Melayu kelas pertengahan terhadap pendidikan agama' sebagai jodol kajiannya. Pada peringkat awal calon ini berkemungkinan ingin mengkaji sikap dan kefahaman masyarakat terhadap pendidikan agama tetapi pembacaan mengalih minatnya kepada persoalan-persoalan yang dihadapi oleh golongan Melayu kelas pertengahan antaranya ialah pendidikan agama. Ini menyebabkan ke semua perbincangan awalnya termasuk sorotan kajian lepas dan pengulasan teori berkaitan adalah terfokus kepada konsep kelas pertengahan dan golongan Melayu kelas pertengahan. Di akhir kajian dia kembali semula kepada sikap dan kefahaman terhadap pendidikan agama dan ini menyebabkan beliau membuat analisis tanpa berpijak kepada teori dan kefahaman sebenar terhadap masalah kajiannya kerana asas teorinya ialah golongan kelas menengah, tidak kefahaman terhadap pendidikan agama. Analisisnya di akhir disertasinya tidak berasaskan teori yang jelas dan dengan itu kurang berkesan sekali.

Untuk memahami masalah kajian, penyelidik selalunya menggunakan dua pendekatan: menguasai teori berkaitan 
dan meneliti penemuan dari kajian-kajian lepas. Haryati Borham $^{16}$ apabila membuat kajian berkenaan minat dan keberkesanan mata pelajaran Tasawwur Islam telah mendahului kajiannya dengan mengkaji teori-teori tentang minat dan keberkesanan dalam pengajaran dan pembelajaran secara umum kemudian menyoroti penemuan-penemuan kajian lepas berkaitan dengan jodol kajiannya. Demikian juga Hasan Basri bin Syahidin ${ }^{17}$ yang telah melakukan perkara yang sama. Hasan telah mendalami teori masyarakat majmuk dan kajian-kajian yang lepas berkaitan masyarakat majmuk dan masalah yang dihadapi oleh masyarakat seperti itu. Dengan cara sedemikian kedua penyelidik ini mampu menjelaskan masalah kajian mereka dengan baik dan dapat menganalisis data lapangan mereka secara berkesan menepati keperluan kajian-kajian mereka kerana mereka menguasai teori dan pengetahuan latar berkaitan. Mereka dapat mengenali bentuk atau jenis data yang harus dikumpul dan bagaimana cara hendak menganalisisdan merumuskannya.

Sebelum mengemukakan kajiannya tentang pengislaman orang Melayu, Mohammad Redzuan Othman ${ }^{18}$ telah membincangkan teori-teori yang terhasil dari penelitian yang telah dilakukan oleh para sarjana lepas. Beliau bukan sekadar membincang teori itu per se malah menyoroti perkembangannya juga. Untuk menjelaskan hal ini beliau telah merujuk kepada kajian

16 Haryati Borham (2004), “Mata Pelajaran Tasawwur Islam: Minat dan Keberkesanan Terhadap Pelajar-pelajar Sekolah Menengah Kebangsaan di Petaling Jaya, Selangor Daru Ehsan," disertasi Sarjana Pengajian Islam, Universiti Malaya.

17 Hasan Basri Syahidin (2006), “Integrasi Masyarakat Majmuk: Suatu Kajian di Kota Medan," disertasi Sarjana Pengajian Islam, Universiti Malaya.

18 Mohammad Redzuan Othman (2005), Islam dan Masyarakat Melayu: Peranan dan Pengaruh Timur Tengah. Kuala Lumpur: Penerbit Universiti Malaya, h. 2-5. 
Jurnal Fiqh: No. 3 (2006)

Pijnappel yang kemudian mendapat sokongan dari kajiankajian para orientalis lain termasuklah J.P. Moquette, R.A. Kern, B. Shrieke, G.H. Bousquet, B.H.M. Vlekke, J. Gonda, T.W. Arnold, R.O. Winstedt, Brian Harrison, Christian Snouck Hurgronje, G.E. Marrison, Kenneth Hall dan juga A.H. Hill. Dari senarai para sarjana itu dapatlah dikatakan bahawa Mohammad Redzuan begitu teliti sekali dalam menimbang hasil kajian-kajian lepas sebelum mengemukakan tesisnya sendiri tentang hal ini bahawa pensejarahan pengislaman orang Melayu harus juga dilihat dari perspektif sumber tradisional Melayu sendiri. Langkah ini dilakukan bagi mempastikan bahawa beliau memahami secara mendalam segala perkembangan yang lepas tentang persoalan kajiannya bagi menjamin keaslian kajiannya nanti kerana beliau tahu apa yang telah dan perlu diketahui dan apa yang perlu diperjelaskan lagi.

Satu kajian menarik telah dilakukan oleh Harry Lee Gradman ${ }^{19}$ tentang teori Analisis Kontrastif. Gradman ialah pensyarah Analisis Kontrastif, satu bidang dalam Linguistik Gunaan. Gradman telah meneliti secara mendalam sehingga dapat menguasai setiap aspek teori ini yang lebih dikenali dengan hipotesis analsisi kontrastif. Dengan keadaan sedemikian, Gradman mempunyai kedudukan yang konkrit untuk menilai teori itu dari segala aspeknyanya. Sebelum kajian ini terhasil, Kontrastif Analisis dianggap sebagai penyelesai kepada masalah pengajaran dan pembelajaran bahasa kedua dan bahasa asing. Banyak badan penyelidikan, khususnya di Eropah, telah ditubuhkan berasaskan teori ini. Kajian Gradman itu adalah begitu berkesan sekali dalam membongkar kelemahan-kelemahan teori itu sehingga menyebabkan 'keruntuhannya' dan melahirkan teori lain yang

19 Harry Lee Gradman (1970), “The Contrastive Analysis Hypothesis; What It Is and What It Isn't," tesis Doktor Falsafah, Indiana University. 
Sorotan Kajian Lepas: Teori dan Amalan Dalam Penyelidikan Islam

kemudiannya dikenali dengan Analisis Kesilapan. Punca kekuatan Gradman ialah penguasaannya secafa mendalam terhadap teori yang berkaitan dengan subjek kajiannya.

Penelitian terhadap teori dan penemuan kajian-kajian lepas juga membolehkan penyelidik menganggarkan kedudukan kajiannya dalam konteks bidang masalah kajian itu dan sumbangan yang akan diberikan oleh kajian yang akan dilaksanakan. Mungkin ianya akan memberi pandangan dari sudut lain terhadap masalah itu seperti yang dilakukan oleh Mohammad Redzuan Othman, menjelaskan kelamahan yang perlu ditangani seperti yang dilakukan oleh dan Harry Lee Gradman, menggunakan teori sebagai panduan untuk menilai keadaan berkenaan seperti yang dilakukan oleh Hasan Basri Syahidin atau menggunakan teori tertentu untuk menilai pelaksanaan sesuatu perancangan seperti yang lakukan oleh Haryati Borham. Penelitian kajian lepas juga boleh mendorong ke arah penerokaan atau penciptaan alat atau kaedah tertentu seperti yang dilakukan oleh Hari Krishnan Mittal ${ }^{20}$ berjudul 'Design and Performance of Tailings Dams', Moh Hak-serh ${ }^{21}$ 'The Design of Minimum Cost Telephone Junction Network' dan Edgardo Esteban Agno ${ }^{22}$ mengenai kaedah baru dalam energy education.

Sesuatu masalah kajian atau mana-mana sahaja masalah sudah pasti ada kaitan atau hubungan dengan sesuatu masalah yang lain atau ada kaitan dengan fenomena tertentu. Ini adalah satu lagi tujuan sorotan kajian lepas, iaitu, mengenalpasti dan memahami masalah-

20 Hari Krishnan Mittal (1974), “Design and Performance of Tailings Dams," tesis Doktor Falsafah, University of Alberta.

21 Moh Hak-serh (1973), "The Design of Minimum Cost Telephone Junction Network," disertasi Sarjana Sains, University of Singapore.

22 Edgardo Esteban Agno (1980), "A Proposed Model on Energy Education for National Development of the Philipines with Emphasis on the Planning and Implementation Roles of Vocational Technical Eduation," tesis Doktor Falsafah, Florida State University. 
Jurnal Fiqh: No. 3 (2006)

masalah dan yang ada kaitan dengan masalah kajian. ${ }^{23}$ Masalah kenakalan pelajar di sekolah mungkin ada kaitan dengan masalah keluarga, kemiskinan, sistem pendidikan sendiri, pengaruh rakan sebaya, urbanisasi dan banyak lagi. Menumpukan kajian hanya kepada kenakalan sahaja tidak akan dapat menyelesaikan masalah itu. Selain dari itu sesuatu masalah itu ada yang merentasi beberapa bidang. Masalah kesihatan boleh dilihat dari pespektif perubatan sendiri, boleh juga dari perspektif kejuruteraan, iaitu, kejuruteran bio-perubatan, dari perspektif psikologi dan pendidikan dan juga dari persektif sosial lain seperti kepercayaan, adat resam, pantang larang, dan sebagainya. Walau pun sesuatu kajian itu tidak mampu untuk meliputi semua bidang dan pespektif tetapi pengetahuan tentangnya adalah perlu untuk proses penyelidikan, paling tidaknya pengkaji berkenaan peka dengan perkembangan dari perspektif yang berbagai itu. Sorotan literatur secara ekstensif akan membantu penyelidik dalam hal ini.

Untuk memahami sesuatu masalah dari sudut puncanya, pengetahuan latarbelakang sejarah serta teori berkaitan adalah perlu. Urutan sejarah akan menjelaskan perkembangan dalam bidang berkenaan. Manakala 'theoretical preliminaries' pula akan menentukan data yang relevan yang perlu dikumpulkan. ${ }^{24}$ Collin Abraham ${ }^{25}$ dalam mencuba untuk mengenalpasti dan menilai semula punca polarisasi kaum di Malaysia dan cuba untuk melahirkan teori bagi penyelesaian masalah sosial itu telah menyoroti sejarah ideologi kolonial dari hampir semua aspek termasuk politik, pentadbiran, dan juga dasar dalam

23 Blanche \& Durrheim (1999), op. cit. h. 19; Blaxter et al. (2002), op. cit. h. 122.

24 Larry Selinker (1972), “Interlanguage' dalam Jack C. Richards, Error Analysis: Perspectives on Second Language Acquisition. London: Longman, h. 31-54.

25 Collin Abraham (2004), The Naked Social Order: The Roots of Racial Polarization in Malaysia. Kuala Lumpur: Pelanduk. 
Sorotan Kajian Lepas: Teori dan Amalan Dalam Penyelidikan Islam

hubungan antara kaum khususnya antara orang Melayu dan bukan Melayu. Dengan cara itu Collin Abraham ${ }^{26}$ merumuskan bahwa teori Furnivall tentang masyarakat majmuk boleh digunakan sebagai kerangka teori atau theoretical framework untuk membantunya dalam proses kajian selanjutnya. Collin Abraham juga meneliti dasar colonial British terhadap orang Melayu, eksploitasi buruh immigrant dari China dan India oleh British bagi kepentingan industri peladangan dan bijih timahnya dan bagaimana buruh itu dibawa masuk. Tindakan ini memberi overview yang jelas kepadanya untuk mengenalpasti jenisjenis sumber primari bagi fakta-fakta yang diperlukan.

Sesuatu kajian terhadap sesuatu masalah berlaku secara khusus serta mendalam. Ini sudah tentu memerlukan persediaan teoritikal yang kukuh seperti yang dibincangkan di atas. Berkaitan dengan itu pengkaji juga perlu berkemampuan untuk menggunakan istilah yang khusus untuk menjelaskan konsep-konsep khusus itu secara tepat. Penguasaan istilah-istilah seperti ini dapat mengelak dari kekeliruan dan menghindarkan penyelidik beating around the bush untuk menjelaskan sesuatu konsep atau keadaan yang khusus. Ketika membincangkan satu aspek dari pengajian teks pada tahun 1966, Julia Kristeva menggunakan istilah intertextuality, yang kemudiannya ditakrifkan sebagai the study of the sociology of text, untuk menjelaskan bentuk kajian yang tertumpu kepada persekitaran tekstual yang membawa kepada pembentukan dan kewujudan teks tertentu. Idiosyncratic atau idiosyncraticism dalam Linguistik merujuk kepada cara seseorang menyatakan sesuatu yang berbeza dengan cara orang lain; dalam Pengajian Islam terdapat perbezaan di antara syariah Islam, hukum Islam dan undang-undang Islam. Ringkas nomenclature atau cara pernyataan dalam setiap bidang pengajian ada istilah-istilah khusus yang

$26 \quad$ Ibid., h, 7-12. 
Jurnal Fiqh: No. 3 (2006)

digunakan yang perlu dikuasai oleh penyelidik bidang berkenaan. Penguasaan terhadap istilah-istilah khusus seperti ini adalah perlu di samping untuk memahami dengan tepat perbincangan oleh para sarjana bidang berkenaan adalah juga dapat diguna dalam proses penyelidikan dan penulisan laporannya kemudian. Penguasaan ini akan menjadikan pernyataan lebih ringkas dan tepat.

Dalam penyelidikan sumber data adalah sangat penting. Sumber itu sama ada dalam bentuk dokumen atau buku, kaedah menghasilkan data kualitatif seperti temubual atau kaedah yang menghasil data kuantitatif seperti soalselidik harus mempunyai kekuatan yang sukar dipertikaikan oleh mana-mana pihak. Sekiranya sumber dipertikaikan data darinya sudah tentu hilang kesahihannya. Kajian-kajian lepas dan pengalaman penyelidiknya yang direkod dalam sesebuah penulisan ilmiah dapat membantu pengkaji untuk mengetahui di mana sumber-sumber itu terdapat. Dari overview terhadap dasar-dasar colonial British, Collin Abraham dapat mengenalpasti bahawa sumber asli bagi maklumat yang diperlukan untuk menjelaskan masalah yang diterokainya dan mahu dicari penyelesaiannya adalah manuskripmanuskrip yang terdapat di Arkib Negara Malaysia, dan juga di Colonial Office dan Foreign Office di London. Mohammad Redzuan Othman membuat pengenalpastian yang sama selain dari sumber tradisi tempatan. Haryati Borham dan Hasan Basri mendapati bahawa masyarakat di lapangan adalah sumber data mereka untuk menjelaskan masalah yang dikaji. Oleh itu kedua-duanya menggunakan soalselidik sebagai kaedah untuk mengumpul data lapangan. Pengenalpastian sumber dan penentuan kaedah yang paling sesuai adalah sangat penting dalam penyelidikan kerana tidak semua kaedah boleh digunakan untuk semua kajian dan hanya sumber yang tepat sahaja yang boleh menghasilkan data atau keterangan yang valid. 
Sorotan Kajian Lepas: Teori dan Amalan Dalam Penyelidikan Islam

Mengenalpasti kaedah yang dianggap paling sesuai bukanlah bererti penyelidik telah menyelesaikan sumber data atau maklumat. Merangka kaedah dan merancang pelaksanaannya dengan mengambil kira kesemua peraturan dan persekitaran berkaitan adalah penting kepada kejayaan proses pengumpulan data yang kukuh. Tujuan penyelidikan ialah untuk mendapatkan jawapan kepada persoalan yang ditimbulkan melalui aplikasi prosedur yang sistematik. Penyelidikan kualitatif yang melibatkan manusia, penentuan dan pemilihan golongan yang mahu dikaji, cara mereka menguruskan kalangan mereka dan bagaimana mereka menggunakan persekitaran untuk manfaat setiap individu dan masyarakat itu memerlukan perancangan yang rapi. Pemilihan dan penentuan yang berkesan juga mengambilkira cara mereka menentukan peranan masing-masing dalam struktur masyarakat mereka serta kesignifikanan setiap simbol dan ritual yang mereka amalkan. ${ }^{27}$ Setiap aspek itu perlu dilihat secara teliti. Fenomena sosial ini perlu dikaji dalam situasinya yang semulajadi dan difahami serta dinilai dalam konteks dan perspektif mereka. ${ }^{28} \mathrm{Hal}$ ini penting bagi mempastikan bahawa keterangan yang diambil itu genuine atau mewakili keadaan yang sebenar. Dalam proses pelaksanaannya, penyelidikan kualitatif-induktif selalunya tidak mempunyai skima yang jelas berbanding dengan penyelidikan kuantitatif-deduktif. Oleh yang demikian pengalaman pengkaji lepas dalam membina prosedur kajian dan melaksanakannya adalah sangat berfaedah sekali untuk diteliti dan diambil panduan. Ini disebabkan kaedah untuk mendapatkan data untuk menjelaskan fenomena seperti di atas dan juga untuk

27 Bruce L. Berg (1998), Qualitatif Research Methods for the Social Sciences (ed. 3). Boston: Allyn \& Bacon, h. 7.

28 Suseela Malakolunthu (2001), "Pengumpulan dan Analisis Data Kualitatif: Satu Imbasan," dalam Marohaini Yusof (Ed.) Penyelidikan Kualitatif: Pengenalan Kerja Lapangan Kajian. Kuala Lumpur: Penerbit Universiti Malaya, h. 121-153. 
Jurnal Fiqh: No. 3 (2006)

mencari pengertian di sebaliknya adalah berlainan dari satu kajian ke kajian yang lain.

Dalam proses pengumpulan data pengkaji selalu berhadapan dengan halangan-halangan yang kalau tidak ditangani dengan berkesan akan mencacatkan mutu kajiannya. Dalam temubual, misalannya, ada informan membatalkan temujanji pada saat akhir di samping ada pula informan yang berkeberatan untuk memberi jawapan yang telus atau menyembunyikan perkara yang sebenar di atas sebab-sebab tertentu. Dalam satu situasi kajian seorang calon ijazah tinggi yang memfokuskan kajiannya terhadap perancangan sistem Ekonomi Islam di Terengganu berhadapan dengan masalah apabila kerajaan PAS di negeri jatuh dan digantikan dengan kerajaan Barisan Nasional yang mempunyai polisi ekonomi yang berbeza. Bagaimanakah beliau menyelesaikan situasi ini? Dalam situasi kajian kedua, Mohd. Ali Hashim, ${ }^{29}$ seorang yang seasoned atau berpengalaman masak dalam perancangan Kurikulum Pendidikan Islam di Malaysia, sama ada Kurikulum Baru Sekolah Rendah (KBSR) mahu pun Kurikulum Baru Sekolah Menengah (KBSM) sehingga segala selok beluk perancangan dan pelaksanaan kurikulum-kurikulum itu begitu sebati dengan dirinya, terpaksa berhempas pulas untuk keluar dari keterikatan dan biasnya dalam meneliti serta menilai kedua-dua kurikulum secara objektif. Cara mengatasi halanganhalangan kajian seperti itu tidak dibincang dalam buku teks kaedah penyelidikan. Hanya pengalaman-pengalaman penyelidik lepas yang terdapat dalam laopran kajian mereka yang yang boleh membantu mencarai jalan penyelesaiannya. Dengan memahami masalah seperti ini penyelidik dapat menyediakan diri dengan kemungkinan-

29 Mohd. Ali Hashim (2002), "Pendidikan Islam KBSR: Asas Pembentukan dan Pelaksanaannya," disertasi Sarjana Pengajian Islam, Universiti Malaya. 
Sorotan Kajian Lepas: Teori dan Amalan Dalam Penyelidikan Islam

kemungkinan yang akan berlaku dan dapat menyediakan perancangan alternatif lebih awal. Dalam hal ini satu teladan boleh diambil dari pengalaman Gradman. Gradman ${ }^{30}$ ialah seorang pensyarah yang bertahun-tahun mengendalikan kursus Contrastive Analysis dan yakin keberkesanan kursus ini dalam perancangan keadahkaedah pengajaran bahasa kedua atau bahasa asing. Setelah beliau membuat kajian untuk Ijazah Doktor Falsafahnya, datanya menunjukkan beberapa kelemahan terdapat pada teori asas disiplin ini, iaitu Contrastive Analysis Hypothesis. Teori ini menyatakan bahawa aspek persamaan antara bahasa ibunda dengan bahasa asing yang dipelajari akan memudahkan pembelajaran dan aspek yang berbeza akan menyukarkan proses pembelajaran. Dalam kajian itu, Gradman mendapati bahawa tidak semua yang sama di antara dua bahasa itu memudahkan pembelajaran dan tidak semua yang berbeza itu menyukarkan pembelajaran, malah sebaliknya boleh berlaku. Gradman yang menghayati teori itu sekian lama menyelesaikan halangan itu dengan mengalih perspektif kajiannya dari tertumpu kepada perbezaan antara bahasa yang dipelajari dengan bahasa ibunda kepada perspektif kesilapan pelajar yang dilakukan oleh semasa proses pembelajaran berjalan. Cara Gradman akhirnya membawa beliau ke teori baru iaitu Error Analysis atau Analisis Kesilapan. ${ }^{31}$

Dalam penyelidikan kuantitatif pula yang selalunya merupakan proses deduktif, sorotan kajian lepas akan menampakkan bagaimana para penyelidik berkenaan mengkonstruksikan teori sebagai premis kajian, menterjemahkan masalah kajian yang abstrak ke dalam bentuk pembolehubah yang dijadikan asas untuk merangka kaedah pengumpulan data lapangan. Laporan kajian lepas

30 Gradman (1970), op.cit.

31 Ibid. 
Jurnal Fiqh: No. 3 (2006)

juga akan menjelaskan tatacara yang dipakai oleh penyelidik untuk mempastikan kaedah-kaedah pengumpulan data mereka menepati ciri kesahihan dan kebolehpercayaan bagi menjamin data yang terkumpul itu betul-betul kuat dan mencukupi untuk dianlaisis. Juga bagaimana para penyeldidik itu melaksanakan kajian mereka serta bagaimana meeka memilih subjek kajian mereka bagi mempastikan bahawa pelaksanaan kaedah itu tepat pada situasi yang sesuai, misalannya siapa yang harus temubualkan atau siapa responden yang akan menjawab soalselidik mereka. Kaedah persampelan secara teorinya adalah mudah dan straight forward tetapi dalam penyelidikan sebenar seribu satu masalah boleh berlaku baik dalam merancang dan lebih-lebih lagi ketika pelaksanaannya. Masalah yang paling biasa dihadapi oleh penyelidik ialah berkaitan dengan pengedaran borang soalselidik dan pemulangannya. Safinar Binti Salleh ${ }^{32}$ mengedar 350 borang soalselidik dalam usahanya untuk mendapat data berkaitan amalan gadaian. Dari jumlah itu hanya 160 borang sahaja yang dikembalikan dan dari jumlah itu 143 (40.86\%) borang yang lengkap dan layak untuk diproses. Haryati Borham ${ }^{33}$ mengedar 110 borang soalselidik sebagai sebahagian dari sampel kajiannya untuk menepati ciri populasi kajiannya. Borang yang dikembalikan hanyalah $85(77.27 \%)$ sahaja. Dari jumlah pulangan seperti itu sudah tentu ia menjejaskan data kajian. Dari situ kita akan dapat mempelajari bagaimana pengkaji berkenaan mengatasi limitasi kajiannya itu dalam menghadapi kekurangan data bagi mempastikan kekuatan kajiannya terjamin.

Selain daripada dapat meneliti pengalaman lepas berkait dengan masalah persampelan seperti di atas, juga

32 Safinar Salleh (2005), "Sistem Gadaian Islam: Pengamalan dan Keberkesanan Operasinya di Negeri Perlis," Disertasi Sarjana Syariah, Universiti Malaya, h. 19.

33 Haryati Borham (2004), op.cit., h. 15-16. 
Sorotan Kajian Lepas: Teori dan Amalan Dalam Penyelidikan Islam

boleh diteliti cara penyelidik itu mengolah atau menganalisis data bagi membuktikan hipotesis dan menjawab objektif-objektif kajian mereka. Analisis data berbeza dari kajian ke kajian mengikut keperluan kajian itu sendiri dan juga imaginasi serta kreativiti penyelidiknya. Sebelum proses analisis, data perlu disemak dan dinilai bagi mempastikan kekuatannya. Fakta atau 'realitas' perlu dipisahkan dari elemen-elemen lain seperti emosi dan sentimen. ${ }^{34}$ Dalam membicarakan tentang metode penggunaan pengalaman peribadi seseorang individu yang tercatat dalam autobiografi atau memoir, Koentjaraningrat ${ }^{35}$ menjelaskan kesulitan yang dihadapi oleh penyelidik ialah berkait dengan kekuatan pengkesahan itu sendiri kerana bahan-bahan seperti itu kebanyakannya ditulis bermotifkan penceritaan untuk dibaca oleh masyarakat awam. Kekuatan data berasaskan ciri-ciri pembuktian akademik mungkin langsung tidak diambilkira oleh penulisnya. Dalam memoirnya, Mustapha Hussein $^{36}$ beberapa kali menyatakan bahawa beberapa pernyataan dan tindakan Ibrahim Haji Yaacob mendorongnya untuk merakamkan semula pengalamannya. Tujuannya adalah untuk memperbetulkan kenyataan bekas ketuanya itu. Kita tidak menafikan keikhlasan dan kejujuran pejuang kemerdekaan Tanah Melayu itu tetapi dalam tindakannya untuk memperbetulkan pernyataan bekas ketuanya itu ada kemungkinan unsur emosi mempengaruhinya sama ada secara positif atau negatif. Menghadapi keadaan seperti ini,

34 Soetandyo Wignjosoebroto (1986), "Pengolahan dan Analiss Data," dalam Koentjaraningrat (ed.), Metode-metode Penelitian Masyarakat. Jakarta: Penerbit PT Gramedia, h. 269-291.

35 Koentjaraningrat (1989), “Metode Penggunaan Data Pengalaman Individu," dalam Koentjaraningrat (ed.), Metode-metode Penelitian Masyarakat. Jakarta: Penerbit PT Gramedia, h. 158-172.

36 Mustapha Hussein (2005), Malay Nationalism Before UMNO: The Memoir of Mustapha Hussein. Insun Mustapha (terj), Jomo K.S. (ed). Kuala Lumpur: Utusan Publication and Distributor, h. 145-150. 
Jurnal Fiqh: No. 3 (2006)

penyelidik semasa membuat sorotan kajian lepas dan semasa menganalisis datanya perlu berhat-hati dan berkeupayaan untuk memilih pernyataan yang lebih tepat, perbezaan pendapat, membezakan di antara fakta (atau 'realitas') dengan unsur-unsur lain yang sifatnya nonacademic, seperti emosi, silap tanggapan atau ingatan, lupa, dan sebagainya. Misalannya Ramlah Adam ketika meriwayatkan sejarah hidup Dr. Burhanuddin al-Helmy mengatakan bahawa tokoh itu berangkat ke India untuk melanjutkan pelajaran ke peringkat tinggi pada tahun 1934. Ramlah Adam menjelaskan dalam nota kakinya mengapa beliau mengatakan tarikh itu lebih tepat berbanding dengan tarikh-tarikh lain seperti berikut:

Beberapa penulis mengatakan Dr. Burhanuddin pergi ke India pada tahun 1928 atau 1929, dengan berdasarkan tulisan Saliha Haji Hassan, yang mulamula menulis riwayat hidup Dr. Burhanuddin dalam bentuk akademik. Namun dalam tulisannya yang terbaharu, iaitu dalam seminar Biografi Politik Malaysia pada tahun 1986, beliau mengatakan Dr. Burhanuddin pergi ke India pada tahun 1934. Menurut Haji Halim, adik Dr. Burhanuddin, pemergian abangnya pada sekitar tahun 1933. Ini bermakna, tahun 1930-an lebih hampir. ${ }^{37}$

Penjelasan nota kaki Ramlah Adam itu di samping menunjukkan kegigihannya dalam mengumpul maklumat sejarah serta ketelitiannya dalam menilai sumber data berkenaan juga menampakkan kepekaannya terhadap setiap maklumat yang terkumpul. Demikian juga menampakkan elemen kekritisan dalam penulisannya. Tradisi akademik ini, iaitu, kegigihan, ketelitian dan kekritisan, yang menjadi amalan Ramlah Adam perlu dipelajari dan dihayati oleh penyelidik-penyelidik lain bagi

37 Ramlah Adam (1996), Burhanuddin al-Helmy. Kuala Lumpur: DBP, h. 8 . 
membolehkan mereka menghasilkan penulisan ilmiah yang kukuh dan bermutu.

Secara ringkasnya kaedah pembentukan sampel atau penentuan subjek kajian dan pelaksanaannya adalah tidak kurang keutamaannya dari kaedah pengumpulan data sendiri. Sekiranya pincang pada sampel sudah tentu ianya akan menjejaskan keutuhan data walau pun perancangan pada awalnya sangat baik. Demikian juga pada aspek analisis data, pengalaman penyelidik lalu itu perlu diambil teladan, termasuk juga pengalaman mereka dalam membersihkan data kerana data yang terhasil dari kaedah yang baik dan dilaksanakan ke atas sampel yang dibentuk dengan baik kalau tidak dianalisis yang cara yang betul dan berperancangan hanya akan melahirkan rumusan yang tidak tepat.

Di akhir sorotan literatur penyelidik seharusnya berkemampuan untuk menyatakan dengan jelas persoalan yang akan ditelitinya, tujuan yang akan dicapainya serta berkemampuan untuk merangka kesemua kaedah yang diperlukan. Beliau juga perlu dapat mengenalpasti sumbersumber rujukan yang autentik. Demikian juga beliau dapat mengetahui siapa atau pihak mana yang berautoriti dalam masalah kajian itu untuk memudahkannya membuat rujukan.

Pernyataan sorotan literatur hendaklah padat dan dapat meyakinkan pembaca bahawa pengkaji telah membuat persediaan rapi sebelum kajian dilakukan. Dalam hal ini Berg $^{38}$ menyatakan, The rule of thumb in writing literature reviews is to keep them long enough to cover the area, but short enough to remain interesting. Pada dasarnya terdapat dua cara yang biasa dilakukan oleh penyelidik untuk mengulas kajian-kajian lepas, iaitu secara menyenaraikan kajian-kajian dan mengulasnya satu

$38 \quad$ Bruce L. Berg (1998), op.cit., h. 258. 
Jurnal Fiqh: No. 3 (2006)

persatu dan diakhiri dengan menyimpulkan perbicangan menyeluruh manakala cara kedua membincang hasil-hasil kajian secara perbandingan. Mohd. Mohadis Bin Yasin ${ }^{39}$ dan Hassan $\mathrm{Ab}$. Rahman ${ }^{40}$ menggunakan cara yang pertama. Kedua-dua penyelidik ini menyenaraikan kajian lepas dan membincangkan penemuan-penemuannya satu persatu secara ringkas kemudian membuat kesimpulan pada akhirnya.

Ridzwan Ahmad pada dasarnya juga menggunakan cara pertama itu tetapi pendekatan dalam perbincangan adalah berbeza. Ridzwan mengulas penemuan setiap kajian serta menilai skop yang diliputi dan tahap yang telah dicapai. Pendekatan ini membolehkannya mengenalpasti sejauh mana telah dikaji tentang masalah kajiannya dan di mana ruang-ruang yang belum disentuh atau masih kesamaran. Ridzwan juga menyoroti pendapat-pendapat ulama klasik berkenaan subjek kajiannya seperti alJuwayni, al-Ghazzali, al-Amidi, Izz al-Din Abd al-Salam dan lain-lain lagi. Pendekatan yang sama juga digunakan oleh A. Kadir Sobur. ${ }^{41}$ Tetapi A. Kadir lebih menumpukan kepada perbandingan penemuan kajian dengan teori-teori berkaitan.

Cara kedua berbentuk perbandingan. Hasil-hasil kajian lepas diperbanding, diadun berdasarkan teori-teori berkaitan dan dirumuskan. Cara kedua ini memberi ruang

39 Mohd. Mohadis Yasin (2005), "Pelarasan Pentadbiran Hal Ehwal Islam Malaysia: Kajian di Jabatan Kemajuan Islam Malaysia (JAKIM)," tesis Doktor Falsafah, Universiti Malaya, h. 10-22.

40 Hassan Ab. Rahman (2004), "Pemakaian Prinsip-prinsip Keterangan Dalam Peruntukan Statut-statut Keterangan Syariah Malaysia: Satu Kajian Perbandingan Dengan Peruntukan Akta Keterangan 1950, Tumpuan Khusus Pada Bayyinah, Syahadah dan Qarinah," tesis Doktor Falsafah, Universiti Malaya, h. xLvii-Liv.

41 A. Kadir Sobur (2005), “Teologi al-Ash'ari dan Pengaruhnya Terhadap Masyarakat Islam Provinsi Jambi, Indonesia," tesis PhD Akademi Pengajian Islam Universiti Malaya. 
kepada penyelididik untuk menilai setiap penemuan yang lepas, melihat masalah kajian dari perspektif penemuanpenemuan itu dan juga dari perspektif teori-teori berkaitan. Inilah yang telah dilakukan oleh Collin Abraham yang telah memecahkan masalah kajian kepada masalahmasalah yang lebih khusus dan mengulaskannya secara terperinci berdasarkan kajian lepas dan juga teori berkaitan. Dalam lain perkataan perbincangkan yang berasaskan kepada teori serta penemuan kajian itu sudah pasti akan lebih mendalam. Dengan cara sedemikian ruang-ruang yang belum diterokai dapat dikenalpasti dengan jelas. Selain dari itu pendekatan ini membolehkan penyelidik menguasai teori-teori berkaitan secara lebih dekat dengan amalannya dan membolehkan mereka menggunakan teori-teori itu secara lebih yakin dalam proses kajian nanti.

Hassan Ab. Rahman, Mohd. Mohadis Yasin, Idris Awang, ${ }^{42}$ Ridzwan Ahmad dan A. Kadir Sobur membincang kajian-kajian lepas sebagai sebahagian dari bab pendahuluan, iaitu bab pertama tesis mereka. Manakala Haryati Borham, Hasan Basri Syahidin dan Collin Abraham ${ }^{43}$ membincangkan kajian-kajian lepas mereka secara ekstensif dalam satu bab khusus.

Secara ringkasnya sorotan kajian lepas yang dilakukan secara mantap, intensif dan ekstensif akan membolehkan penyelidik memahami masalah kajiannya secara menyeluruh sama ada dari sudut teoretikalnya, demikian jaga dari sudut persekitaran atau konteksnya. Sorotan yang mantap itu akan memudahkan proses pengkajian berikutnya dan mungkin juga akan memendekkan tempoh kajian kerana pengkaji telah mendapat gambaran yang

42 Idris Awang (1997), "A Comparison of Present Time and Tense in English and Malay," tesis Doktor Falsafah, Universiti Malaya, Chp. One.

43 Collin Abraham (2004), op.cit. 
Jurnal Fiqh: No. 3 (2006)

jelas tentang sumber data, jenis data yang diperlukan, kaedah pengumpulan data yang paling sesuai serta dapat mengenalpasti subjek atau sampel yang dengan tepat. Beliau juga telah mempunyai kekuatan teori yang akan membantunya dalam proses mengolah dan menganalisis data yang terkumpul itu. Dalam lain perkataan penyelidik itu tahu apa yang diperlukan dan bagaimana hendak melakukannya. Dengan demikian beliau akan dapat melaksanakan kajian secara independent tanpa banyak bergantung kepada penyelianya. 